\title{
The E-Learning Module Arrangement Budgeting Based on Activity-Based Budgeting Model (Case Study: The IT Enterprise in Jakarta)
}

\author{
Wayan Santiasih $^{1}$, Nengzih ${ }^{2}$ \\ ${ }^{1}$ Universitas Mercu Buana, Master Student in Accounting Department, Faculty of Economy Jakarta, \\ Indonesia \\ ${ }^{2}$ Universitas Mercu Buana, Accounting Department, Faculty of Economy Jakarta, Indonesia
}

\begin{abstract}
:
Budget is one of the management decision-making tools, from activities to finance. One of the budgeting models can be applied is an Activity-Based Budgeting (ABB) model. The objective of this research is to propose the application of the ABB model in IT Enterprise in Jakarta. The object in this research is budgeting for e-learning projects that carried out by IT Enterprise in Jakarta. In the present time, the budgeting model applied is included in the traditional budgeting system, namely the Incremental budgeting model, in which the budgeting is conducted based on the budget in the previous year therefore sometimes the information used is less accurate. This research shows the differences between the ABB model and the Incremental budgeting model, as well as the evaluation of the application of each model. This research is aquantitative research, with descriptive exploratory research type in a case study. Research data was obtained from face to face interviews, observation of activities and documentation. ABB modeling is carried out by detailing activities in e-learning projects including human resources used, then compiling employee costs for these activities. The results of $\mathrm{ABB}$ modeling show that $\mathrm{ABB}$ has capabilities to provide more accurate information about activities, costs for activities, work process time, amount of human resources needed, total employee costs and project profit / loss. It can be concluded that the ABB model can provides the budgeting model needs of IT Enterprise.
\end{abstract}

Keywords: Activity-Based Budgeting, Budget, Human Resources, Incremental Budgeting.

\section{Introduction}

The enhancement of domestic economy condition is triggered by information technology and communication development. Based on that condition, the innovative approach to maintain the proper economy condition must be conducted. One of the innovative approaches to micro scale business is enterprise budgeting system. The enhancement of earn budgeting and cost optimization toward the budget balancing on the dynamic social and economy condition will determine the social development, national economy and standard of living [1].

All of the business lines have to arrange the budget [2]. The budget helps the business owner and manager to make plan and control to actual business performance. The budget describes the manager expectation about the earning, price and cost. All of the enterprises will obtain the value from plan and control provided the budgeting system, even it is the small business or non-profit entity. The objective of budgeting system is providing the management based on evaluation and decision as the basic of the management plan and control [3].

In the present time, budgeting is very important thing due the economy development indicator and performance of management will be planned and controlled along it [4]. If the purpose is to evaluate the manager then only those items directly controllable by the manager should be included in the financial performance measure [5]. The financial performance is an indicator often used to measure the success of a company [6]. Based on that statement, the budgeting will be the tools of internal control system of enterprise. As the predevelopment, the internal control system will state as internal examination [7] through five dimensions effectiveness variable follows environmental control, risk assessment, activity control, 
information then communication and monitoring [8]. Finally, the budgeting system is designed to business plan and control [9].

One of budgeting approach is Activity-Based Budgeting (ABB). ABB is including on Zero Level Budgeting category. By the Zero Level Budgeting, the budget arrangement starts from operational planning without the official fund [10]. By this method, the enterprise has to arrange the activity at every time along the project budgeting process. $\mathrm{ABB}$ enable the enterprise to predict the changes of project resources demand to obtain the efficiency and the amendment of work and volume [11]. That method is the reverse of Incremental Budgeting which included to Achieved Level Budgeting. On the Incremental Budgeting, the budget is prepared based on previous budget or actual performance as recent budgeting process [10]

There are many researches about the application of $\mathrm{ABB}$ in many enterprise sectors. The application of ABB under low-IT environment condition is conducted by [12] and provides the information that the benefit of $\mathrm{ABB}$ can be obtained without IT support and it depends on the human resources. The ABB can be applied through food supply enterprise [4]. Based on that research there are the difference budget on producing food use $\mathrm{ABB}$ or traditional budgeting. Mining industry in Romania became the research object by [13] and claims that the ABB method can enhance the effectiveness of production components. Other enterprises are taken as $\mathrm{ABB}$ research object by many researchers like as NonManufacturing Companies [14], Agricultural Company [15], Economic Security Company [16], and local government [17].

This research chooses the e-learning module project done by one of IT enterprise in Jakarta, Indonesia as the object. At every year, the model budget is applied by that enterprise is Incremental Budgeting. The arrangement of recent budget based on previous budget annually. The problem of this system is uncontrolled when the over budget occurs. The source of over budget can't be detected while the incremental budgeting applied. Based on that problem, the objective of this research is giving understanding about activity-based budgeting. Detailing the production component of the elearning module is expected giving more information about actual budget performance. If the source of project loss is known, the management can take decision about how to maintain the budget.

\section{Theoretical Consideration}

The budgeting process usually directed by budget committee that follows sell manager, production manager, chief engineer, chamberlain and system driver. The main function of budget committee are follows [18]:

1. Decide the general policy.

2. Ask the estimation of individual budget.

3. Suggest the revision of individual budget estimation.

4. Accept the budget and next revision.

5. Analyze the budget report.

6. Make the recommendation against efficiency enhancement.

Activity-Based Budgeting (ABB) focuses on activity which necessary to produce and sell the product and service. ABB distinguishes indirect cost onto distinguished homogenous activity cost pool. The management use cause and effect criteria to identify the cost driver for each indirect cost pools [19]. $\mathrm{ABB}$ is the novel approach on budgeting system. The popularity of ABB enhance because this model provides the relationship activity to the expenditure and giving the understanding to the top level management about the allocation of full fund to service and resources [10]. The theory behind of $\mathrm{ABB}$ is very simple. The core of $\mathrm{ABB}$ as budget planner, all of the resources procurement (manpower, equipment and building) is determined at pre-periodic budget and before the demand of resources known surely [11].

ABB is the budgeting model which aim to authorize the application of the resources suitable to the activity to achieve the production budget and volume [5]. The $\mathrm{ABB}$ is process oriented budgeting model [20]. In other hand, ABB is the differentiation of Activity-Based Costing model (ABC). ABC model provides the expenditure of resources for activities and then the object cost (product, service and so on) determined based on the cost activity assigned. ABB model is the opposite of model ABC 
process. The different of $\mathrm{ABB}$ model and $\mathrm{ABC}$ model described on Fig. 1 [20].

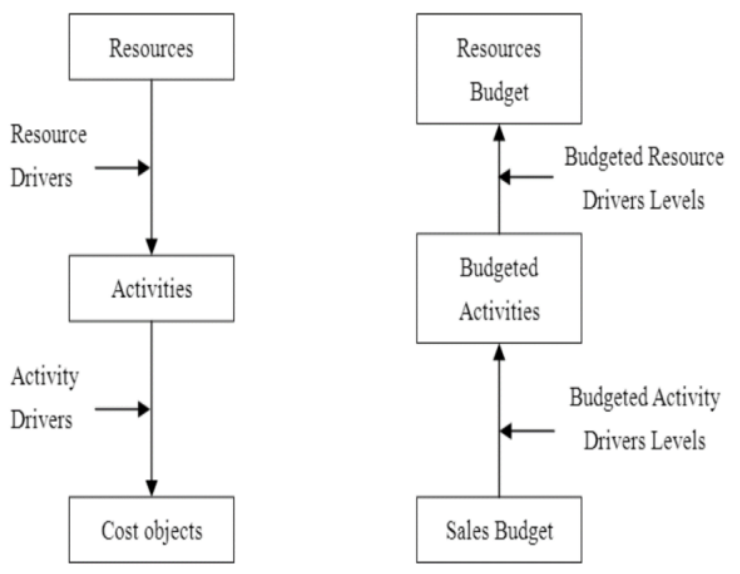

Fig. 1: The Illustration of the Difference of $A B B$ and ABC Model

The Fig. 1 describes that ABB starting from the plan of earning or sales. By the earning plan, then conduct activities arrangement until the cost of the resources involved. Therefore, the output budget determines the inquiry of activity and then used to predict the inquiry of resources. Theoretically, there are five steps on Activity-Based Budgeting modeling. The steps are arranged follows [5]:

1. Production and earning volumes estimation planed by each products or customers.

2. Estimate the activities required.

3. Determine the resources required to conduct the organized activities.

4. Estimate each the resources required to achieve activity demand.

5. Execute on resources capacity then appropriate to projection.

Special note for step two, where the activity requirements estimation, are conducted in detail as example ordering, receiving, scheduling and processing. On Activity-Based Budgeting implementation, each the activity required to produce and sell the product or service have to identified in detail. The amount of activity cost estimation has to derived on each activity. Based on the activity amount requirements, then determine the resources required to conduct the activities. The amount and kind of resources are detailed on this stage. On this stage, the resources requirements are generated and then converted to the sum of requirements to execute the one activity. The sum of resources requirements, are distinguished based on the kind of resources used, as example manpower, equipment and so on. The final stage of $\mathrm{ABB}$ is comparing the estimation of resources required against resources availability. If the resources estimation exceeds the capacity of the resources, then the additional resources are required on budget planning.

Activity-Based Budgeting has advantages follows supporting the sustainability improvement and process management. Because the activity consumes resources, $\mathrm{ABB}$ model can be applied to minimize the cost through removing the useless activities and improving the efficiency of activities [2]. Many managers from UK have reported the rank of advantages as Activity-Based Budgeting [19]:

1. Eligibility to organize the budget which more realistic.

2. Identify the resources required better.

3. Make the connection between cost and output.

4. Make the connection between cost and employee responsibility clearly.

5. Identify the gap of budget.

Another budgeting model discussed in this research is the Incremental Budgeting model. The incremental budgeting model is budgeting approach based on previous year budget. On the conventional budgeting approach, the indirect cost and support activity prepared as the basis of incremental budgeting. This has meant that the recent operational budget is initial value for budgeting in next year. The value of this basis arrangement enhanced because of the inflation effect. By the conventional budgeting, the indirect cost and support activity arranged gradually [5]. It means that, the available operation and allowance budgeted or planned on recent activity are taken as initial point for next year budget preparation. The basis appropriated for many changes, as examples are the changes of product variations, volumes and price. This condition is expected occurs along the next budget period. 


\section{Methodology}

This research can be simply described as conceptual framework. Fig. 2 describes the conceptual framework of Activity-Based Budgeting modelling.

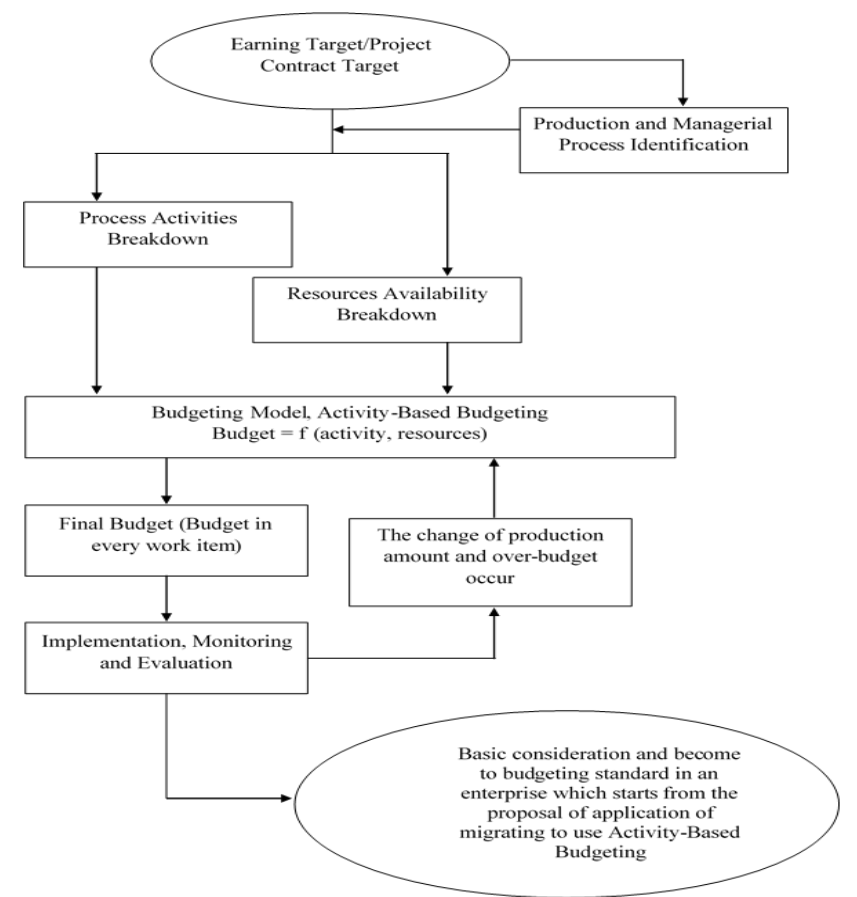

Fig. 2: Activity-Based Budgeting Conceptual Framework

Based on Fig. 2, the Activity-Based Budgeting modelling is started from project contract target then breakdown on process activity and resources availability are conducted. Activity-Based Budgeting is implemented entire of department. Monitoring and evaluation conducted periodically.

\section{Data Collection}

The research data obtained through some data collection methods. It is follows:

1. Interview. Interview is integrated communication between more than or equal two persons. There are many kinds of interview. Individual or grouping interview perhaps not structured or structured and conducted by face to face, by phone or online. Non-structured interview is an interview which the interviewer meets the correspondence without the sequence of questions. In other hand, structured interview is an interview which the information needed have been known [21]. This research uses structured interview and entire of questions formulated by text. The interview conducted face to face and by phone.

2. Observation. The observation is a direct visual of research object to looking activity closer [22].
The observation related to scanning, typing analyzing, and interpreting and it is about behavior, action or event [21]. In this research, the observation conducted through direct participation on entire system related to enterprise budgeting process.

3.Documentation. The objective of documentation is to obtaining direct data from research object follows relevance books, policy, activity reports, pictures, film and other relevant data [22]. The entire of documentation in this research are primary data taken from video and e-learning project archive at 2017. That data follows contract value, the component of making video and e-learning cost, the budget of making video and e-learning project at 2017 and entire of resources involved (manpower, equipment, and money).

\section{Analysis Method}

The analysis focusing in this research distinguished to budgeting analysis based on incremental approach and activity-based approach. The explanation of them can be described below.

\section{Incremental Budgeting Analysis}

a. Making video and e-learning cost planning at current period (2017) based on similar project cost at previous year.

b.The evaluation of incremental budgeting implementation.

\section{Activity-Based Budgeting Analysis}

a.Estimating the earning plan of video and elearning project obtained at current period (2017).

b.Activities breakdown related to video and elearning project including the estimation of work process of each activity. Each process has detail of activity related to video and elearning project.

c. Calculate the resources cost for each primary activity related to e-learning project finalization. Thus, the cost for each activity plan is clear.

d.After the cost of each activity obtained, then that cost allocated to product cost. Therefore, the sum of cost required for finalization video and e-learning project are obtained.

e. Listing entire of resources available related to production process of video production and e-learning. Each resource arranged based on unit and basic cost of each resource. 
f. Estimate the requirement of the number of resources for each primary activity.

g.Execute the arrangement of useless resources capacity during the activity process.

h.Evaluate the hourly cost capacity of each activity, thus the analysis of resources cost for next period can be conducted.

\section{Result and Discussion}

As explained in previous part, this research will observe and analysis the budgeting distinguished into two approach, incremental budgeting (used in present time) and Activity-Based Budgeting. It is conducted to obtain the difference result between incremental budgeting and Activity-Based budgeting. Therefore, the advantages and disadvantages of both of them can be observed.

\section{The Incremental Budgeting Analysis}

Before arrange the budget, the first thing have to conducted by enterprise is determine how long the time period of project. Table 1 describe the duration of video and e-learning project.

Table 1: The Time Period of Project (Planning)

\begin{tabular}{|c|l|c|c|c|}
\hline Num & \multicolumn{1}{|c|}{ Task Name } & $\begin{array}{c}\text { Duration } \\
\text { (Days) }\end{array}$ & $\begin{array}{c}\text { Start } \\
(\mathbf{2 0 1 7})\end{array}$ & $\begin{array}{c}\text { Finish } \\
(\mathbf{2 0 1 7})\end{array}$ \\
\hline 1 & $\begin{array}{l}\text { Video and E-Learning } \\
\text { content CBT Development }\end{array}$ & 96 & Mar 2nd & Aug 3rd \\
\hline
\end{tabular}

Data Courtesy: Archive

Although the management of the company has determined the period of completion of the production process, but in its realization, there is a difference in the period of completion. As illustrated in Table 2.

Table 2: The Time Period of Project (Realization)

\begin{tabular}{|c|c|c|c|c|}
\hline No. & Task Name & Duration & $\begin{array}{c}\text { Start } \\
\text { (2017) }\end{array}$ & $\begin{array}{c}\text { Finish } \\
\text { (2017) }\end{array}$ \\
\hline 1 & $\begin{array}{l}\text { Video \& Modul E-lerning } \\
\text { content CBT Development }\end{array}$ & 230 days & Jan 2 & Des 29 \\
\hline
\end{tabular}

Data Courtesy: Archive

The budget of e-learning project are follows variable cost and fixed cost. Variable cost determining is related to video and e-learning production process at 2016. The additional cost possible will be involved. Table 3 is the list of variable cost component and value.

Table 3: The Variable Cost (on Million IDR)

\begin{tabular}{|c|c|c|c|c|c|}
\hline Num & Cost Item & Unit & Unit Cost & Volume & Value \\
\hline \multicolumn{6}{|c|}{ I. Direct Additional Employees Cost } \\
\hline 1 & Programmer & Person & 100 & 1 & 100 \\
\hline 2 & Instructional Designer & Person & 24 & 2 & 48 \\
\hline 3 & Ilustrator & Person & 32 & 1 & 32 \\
\hline 4 & Graphic Designer & Person & 24 & 2 & 48 \\
\hline 5 & $\begin{array}{l}\text { Voice Over and } \\
\text { Content Writer }\end{array}$ & Person & 8 & 2 & 16 \\
\hline \multicolumn{5}{|c|}{ Subtotal I } & 244.00 \\
\hline \multicolumn{6}{|c|}{ II. Equipment Cost } \\
\hline 1 & Personal Computer & Pcs & 1.2 & 2 & 2.4 \\
\hline 2 & Notebook & Pcs & 2.25 & 4 & 9 \\
\hline 3 & Electricity & Ls & 2 & 1 & 2 \\
\hline 4 & Software & Ls & 20 & 1 & 20 \\
\hline \multicolumn{5}{|c|}{ Subtotal II } & 33.40 \\
\hline \multicolumn{6}{|c|}{ III. Other Cost } \\
\hline 1 & Sales Commision & Ls & 10 & 1 & 10 \\
\hline 2 & Project Incentive & Ls & 2.5 & 1 & 2.5 \\
\hline \multicolumn{5}{|c|}{ Subtotal III } & 12.50 \\
\hline & Total Varia & le Cost (I & I+III) & & 289.90 \\
\hline
\end{tabular}

Data Courtesy: Archive

Determining the cost on entire of the Table 3 based on production cost at 2016 and conducted at lately 2016. The planning of fixed cost of video and elearning production based on the plan at 2017. The fixed cost components listed on Table 4.

Table 4: The Fixed Cost (on Million IDR)

\begin{tabular}{|c|l|l|c|c|r|}
\hline Num & Fixed Cost Components & Unit & Unit Cost & Volume & Value \\
\hline 1 & Enterprise Employee Cost & Ls & 700 & 1 & 700 \\
\hline 2 & Allowance & Ls & 40 & 1 & 40 \\
\hline 3 & Bonus & Ls & 50 & 1 & 50 \\
\hline 4 & Religion Day Allowance & Ls & 50 & 1 & 50 \\
\hline 5 & Overtime Incentive & Ls & 35 & 1 & 35 \\
\hline 6 & Employee Training & Ls & 3 & 1 & 3 \\
\hline 7 & Office Rent Cost & Ls & 80 & 1 & 80 \\
\hline 8 & Manintenance & Ls & 2 & 1 & 2 \\
\hline 9 & Equipment Cost & Ls & 15 & 1 & 15 \\
\hline 10 & Health and Employement & Ls & 85.5 & 1 & 85.5 \\
\hline 11 & Transportation & Ls & 7 & 1 & 7 \\
\hline 12 & Stationary & Ls & 8 & 1 & 8 \\
\hline 13 & Internet & Ls & 1 & 1 & 1 \\
\hline & & & & $\mathbf{1 0 7 6 . 5 0}$ \\
\hline
\end{tabular}

Data Courtesy: Archive 
If the total incremental budgeting obtained from variable cost and fixed cost, hence the value of incremental budgeting for video and e-learning production along one year are 1366.40 Million

Rupiah. After finishing the project, management recalculate for total cost of e-learning project. Realization of total cost for e-learning project are IDR.414,358,475 (include manpower cost = IDR.391,805,547).

\section{The Activity-Based Budgeting Analysis}

The enterprise budget arrangement usually has most dominant cost. In this case, the dominant cost is on manpower cost. This makes a sense because, in video and e-learning production, the employee taking the dominant role entire the process. Therefore, the first step in Activity-Based Budgeting is arrangement of time-driven activity.

\section{Time-Driven Activity}

The first stage of Activity-Based Budgeting model development is determining the time-driven activity. In this stage, the result of interview is very important. Not only interview, but also the archive document is necessary. All of data collecting related to video and e-learning production process. The component of time-driven activity described below:

1) Determine the primary activity. The primary activity in video and e-learning project in sequence are follows contract bidding, video and e-learning ordering, resources arrangement, document completing, and production process.

2) Availability resources breakdown. The primary resources to produce the video and e-learning module are manpower and money. The manpower resources necessary are follows business manager, sales marketing, accounting and finance manager, taxes staff, daily record staff, daily cash staff, account receivable department, human resources department, general administration staff, production supervisor, instructional designer, graphic designer, illustrator, programmer, voice over and content writer.
3) Time estimation and resources capacity for each primary activity. Those activity have been stated at first point.

4) Calculate the capacity cost for resources. In this step, the effective work hours are calculated. Table 5 describes the time necessary weekly to conduct video and e-learning production.

Table 5: Work Time Necessary to Conduct Production

\begin{tabular}{|c|c|l|c|c|}
\hline Day & Time & Work Hours & Work Days & $\begin{array}{c}\text { Total Work } \\
\text { Hours }\end{array}$ \\
\hline $\begin{array}{c}\text { Monday until } \\
\text { Thursday }\end{array}$ & $08.00-11.45$ & 3 Hours, 45 Minutes & 4 & 15 \\
\hline \multirow{2}{*}{ Friday } & $13.00-17.00$ & 4 Hours & 4 & 16 \\
\cline { 2 - 5 } & $08.00-11.00$ & 3 Hours & 1 & 3 \\
\hline \multicolumn{3}{|c|}{ Weekly Work Hours } & 1 & 4 \\
\hline \multicolumn{3}{|c|}{ Weekly Work Minutes } & $\mathbf{3 8}$ \\
\hline
\end{tabular}

If the effectiveness of work hours taken as $80 \%$, then the weekly work hours become 1,938 minutes per week. This value derived against national holiday entire year, hence the effective work hours become 1,486 hours per year. Furthermore, it calculates the cost of resources, which is calculated based on the employee's main income for the main activities carried out by employees. Following are the calculations:

Table 6. Standard Hourly Resources Costs

\begin{tabular}{|c|c|c|c|c|c|c|}
\hline No & Position & $\begin{array}{c}\text { Number of } \\
\text { Employees } \\
\text { (Persons) }\end{array}$ & $\begin{array}{l}\text { Total Average } \\
\text { Income for } \\
\text { Each Month } \\
\text { (IDR) }\end{array}$ & $\begin{array}{l}\text { Total Income for } \\
\text { One Year } \\
\text { (IDR) }\end{array}$ & $\begin{array}{c}\text { Capacity of } \\
\text { Effective } \\
\text { Time-Work } \\
\text { (Hour) }\end{array}$ & $\begin{array}{c}\text { Standard } \\
\text { Resources } \\
\text { Cost Per } \\
\text { Hour } \\
\text { (IDR) }\end{array}$ \\
\hline \multicolumn{7}{|c|}{ a). Employees with mult functions: } \\
\hline 1 & Business Manager & 1 & $12,808,954$ & $153,707,447$ & 1,486 & 103,437 \\
\hline 2 & Accounting \& Finance Manager & 1 & $11,562,287$ & $138,747,446$ & 1,486 & 93,370 \\
\hline 3 & Human Resources Deparment & 1 & $6,341,298$ & $76,095,580$ & 1,486 & 51,208 \\
\hline 4 & Sales Marketing & 1 & $4,293,233$ & $51,518,798$ & 1,486 & 34,669 \\
\hline 5 & Account Receivable Deparment & 1 & $3,803,121$ & $45,637,446$ & 1,486 & 30,712 \\
\hline 6 & Daily-Cash Staff & 1 & $3,693,121$ & $44,317,446$ & 1,486 & 29,823 \\
\hline 7 & Taxes Staff & 1 & $3,736,454$ & $44,837,446$ & 1,486 & 30,173 \\
\hline 8 & Daily-Record Staff & 1 & $3,519,787$ & $42,237,446$ & 1,486 & 28,424 \\
\hline 9 & General and Administrative Staff & 2 & $4,938,356$ & $59,260,276$ & 2,972 & 19,940 \\
\hline \multicolumn{7}{|c|}{$\begin{array}{l}\text { b). Employees in the production process } \\
\text { (available): }\end{array}$} \\
\hline 1 & Supervisor Produksi & 1 & $10,215,419$ & $122,585,027$ & 1,486 & 82,493 \\
\hline 2 & Instructional Designer & 1 & $4,285,884$ & $51,430,605$ & 1,486 & 34,610 \\
\hline 3 & Graphic Designer & 1 & $5,080,975$ & $60,971,703$ & 1,486 & 41,031 \\
\hline 4 & Ilustrator & 1 & $4,656,934$ & $55,883,211$ & 1,486 & 37,606 \\
\hline \multicolumn{7}{|c|}{$\begin{array}{l}\text { Karyawanc). Employees in the } \\
\text { production process (additional): }\end{array}$} \\
\hline 1 & Instructional Designer & 2 & $3,767,045$ & $45,204,545$ & 2,972 & 15,210 \\
\hline 2 & Graphic Designer & 2 & $5,369,318$ & $64,431,818$ & 2,972 & 21,680 \\
\hline 3 & Programmer & 1 & $9,031,061$ & $108,372,727$ & 1,486 & 72,929 \\
\hline 4 & Content Writer & 1 & 250,000 & $3,000,000$ & 1,486 & 2,019 \\
\hline 5 & Voice Over & 2 & $1,185,417$ & $14,225,000$ & 2,972 & 4,786 \\
\hline & Total & & 98,538,664 & $1,182,463,967$ & & \\
\hline
\end{tabular}


Calculate the requirements of resources cost related the primary activity. There are several calculation stages based on activities related to e-learning projects, as follows:

a. Activities related to price offers

\begin{tabular}{|c|c|c|c|c|c|}
\hline No. & $\begin{array}{l}\text { Primary Activity } \\
\text { Description }\end{array}$ & Resource Capacity & $\begin{array}{c}\text { Processing } \\
\text { Time } \\
\text { (Hours) }\end{array}$ & $\begin{array}{l}\text { Standard } \\
\text { Hourly Fee } \\
\text { (IDR) }\end{array}$ & $\begin{array}{l}\text { Resources Fee } \\
\text { (IDR) }\end{array}$ \\
\hline \multirow{2}{*}{1} & \multirow{2}{*}{$\begin{array}{l}\text { Checking Market Prices } \\
\text { or Competitive Prices }\end{array}$} & \multirow{2}{*}{$\begin{array}{l}2 \text { persons: business manager, sales } \\
\text { marketing. ( } 7 \text { documents } x 20 \text { days } \\
\mathrm{x} 5 \text { hours) }\end{array}$} & \multirow{2}{*}{700} & 103,437 & $72,405,931$ \\
\hline & & & & 34,669 & $24,268,613$ \\
\hline 2 & $\begin{array}{l}\text { Consider Production } \\
\text { Costs }\end{array}$ & $\begin{array}{l}2 \text { persons: accounting finance } \\
\text { manager \& director. ( } 5 \text { days x } 5 \\
\text { hours) }\end{array}$ & 25 & 93,370 & $2,334,244$ \\
\hline 3 & $\begin{array}{l}\text { Determination of Sales } \\
\text { Targets }\end{array}$ & $\begin{array}{l}3 \text { persons: business manager, } \\
\text { director, commissioner. (10 days } x \\
5 \text { hours) }\end{array}$ & 50 & 103,437 & $5,171,852$ \\
\hline 4 & $\begin{array}{l}\text { Determination of Bid } \\
\text { Prices }\end{array}$ & $\begin{array}{l}3 \text { persons: business manager, } \\
\text { president director/director, } \\
\text { commissioner. (5 days } \mathrm{x} 4 \text { haours) }\end{array}$ & 20 & 103,437 & $2,068,741$ \\
\hline 5 & $\begin{array}{l}\text { Shipping Price Quote } \\
\text { Letter }\end{array}$ & $\begin{array}{l}2 \text { persons from general } \\
\text { administration staff }(7 \text { documents } \\
\times 5 \text { days } x 4 \text { hours })\end{array}$ & 140 & 19,940 & $2,791,534$ \\
\hline \multicolumn{5}{|c|}{ Total Resources Costs } & $109,040,914$ \\
\hline
\end{tabular}

b. Activities related to video orders and e-learning modules

\begin{tabular}{|c|c|c|c|c|c|}
\hline No. & $\begin{array}{c}\text { Primary Activity } \\
\text { Description }\end{array}$ & Resource Capacity & \begin{tabular}{|c} 
Processing \\
Time \\
(Hours)
\end{tabular} & $\begin{array}{c}\text { Standard } \\
\text { Hourly Fee } \\
\text { (IDR) }\end{array}$ & $\begin{array}{l}\text { Resources Fee } \\
\text { (IDR) }\end{array}$ \\
\hline 1 & Price Agreement & $\begin{array}{l}2 \text { persons: president } \\
\text { director/director, business } \\
\text { manager. (5 days } x \text { hours) }\end{array}$ & 25 & 103,437 & $2,585,926$ \\
\hline 2 & $\begin{array}{l}\text { Preparation of Work } \\
\text { Contracts Until } \\
\text { Endorsement }\end{array}$ & $\begin{array}{l}2 \text { persons: president } \\
\text { director/director, business } \\
\text { manager. (5 days } x \text { hours) }\end{array}$ & 25 & 103,437 & $2,585,926$ \\
\hline 3 & $\begin{array}{l}\text { Project Timeline } \\
\text { Preparation }\end{array}$ & $\begin{array}{l}1 \text { person: staff Instructional } \\
\text { Designer (2 days } \times 5 \text { hours) }\end{array}$ & 10 & 34,610 & 346,101 \\
\hline \multicolumn{5}{|c|}{ Total Resources Costs } & $5,517,953$ \\
\hline
\end{tabular}

c. Activities related to resource adjustments

\begin{tabular}{|c|c|c|c|c|c|}
\hline No. & $\begin{array}{l}\text { Primary Activity } \\
\text { Description }\end{array}$ & Resource Capacity & \begin{tabular}{|c} 
Processing \\
Time \\
(Hours)
\end{tabular} & $\begin{array}{l}\text { Standard } \\
\text { Hourly Fee } \\
\text { (IDR) }\end{array}$ & $\begin{array}{l}\text { Resources Fee } \\
\text { (IDR) }\end{array}$ \\
\hline 1 & $\begin{array}{l}\text { Calculation of Required } \\
\text { Resources }\end{array}$ & $\begin{array}{l}1 \text { person supervisor production (3 } \\
\text { days } x 4 \text { hours) }\end{array}$ & 12 & 82,493 & 989,919 \\
\hline 2 & $\begin{array}{l}\text { Collection of Additional } \\
\text { Resources Needed }\end{array}$ & $\begin{array}{l}1 \text { person human resources } \\
\text { department ( } 8 \text { additional } \\
\text { employees } x 5 \text { days } x 5 \text { hours) }\end{array}$ & 200 & 51,208 & $10,241,666$ \\
\hline 3 & Employee training & $\begin{array}{l}1 \text { person human resources } \\
\text { department }(7 \text { employees } x 10 \text { days } \\
\text { x } 5 \text { jhours) }\end{array}$ & 350 & 51,208 & $17,922,916$ \\
\hline \multicolumn{5}{|c|}{ Total Resources Costs } & $29,154,501$ \\
\hline
\end{tabular}

d. Activities related to project related documents

\begin{tabular}{|l|l|l|r|r|r|}
\hline No. & $\begin{array}{c}\text { Primary Activity } \\
\text { Description }\end{array}$ & Resource Capacity & $\begin{array}{c}\text { Processing } \\
\text { Time } \\
\text { (Hours) }\end{array}$ & $\begin{array}{c}\text { Standard } \\
\text { Hourly Fee } \\
\text { (IDR) }\end{array}$ & $\begin{array}{c}\text { Resources Fee } \\
\text { (IDR) }\end{array}$ \\
\hline \multirow{2}{*}{1} & Quotation letter & $\begin{array}{l}\text { 3 persons: business manager, sales } \\
\text { marketing, staff admin. (7 Quotation } \\
\text { letter x 2 days x } 5 \text { hours) }\end{array}$ & 70 & 103,437 & $7,240,593$ \\
\cline { 5 - 7 } & & & 34,669 & $2,426,861$ \\
\cline { 5 - 6 }
\end{tabular}

\begin{tabular}{|c|c|c|c|c|c|}
\hline \multirow{2}{*}{2} & \multirow{2}{*}{$\begin{array}{l}\text { Work-Contract } \\
\text { Documents }\end{array}$} & \multirow{2}{*}{$\begin{array}{l}3 \text { persons: president director, } \\
\text { business manager, staff admin. (7 } \\
\text { documents } 4 \text { days } x \text { hours) }\end{array}$} & \multirow{2}{*}{140} & 103,437 & $14,481,186$ \\
\hline & & & & 19,940 & $2,791,534$ \\
\hline 3 & \begin{tabular}{|l|} 
Price Agreement and \\
Module Content \\
Description Letter \\
\end{tabular} & \begin{tabular}{|l|}
2 persons: president director, \\
business manager. $(7$ documents $\mathrm{x} 2$ \\
days $\mathrm{x} 5$ hours $)$
\end{tabular} & 70 & 103,437 & $7,240,593$ \\
\hline 4 & Project Timeline & $\begin{array}{l}1 \text { person: Instructional Designer }(7 \\
\text { documents } \mathrm{x} 1 \text { day } \mathrm{x} 5 \text { hours }\end{array}$ & 35 & 34,610 & $1,211,353$ \\
\hline 5 & $\begin{array}{l}\text { Documents for Handover } \\
\text { of Work }\end{array}$ & $\begin{array}{l}1 \text { person supervisor production }(14 \\
\text { documents } \mathrm{x} 4 \text { days } \mathrm{x} 5 \text { hours })\end{array}$ & 280 & 82,493 & $23,098,121$ \\
\hline 6 & Invoice & $\begin{array}{l}1 \text { person: AR department ( } 14 \\
\text { documents } x 2 \text { days } x 2 \text { hours) }\end{array}$ & 56 & 30,712 & $1,719,850$ \\
\hline 7 & Tax invoice & $\begin{array}{l}1 \text { person: taxes staff }(14 \text { documents } \mathrm{x} \\
1 \text { day } \mathrm{x} \text { hour })\end{array}$ & 14 & 30,173 & 422,425 \\
\hline \multirow{5}{*}{8} & \multirow{5}{*}{ Final Project Report } & \multirow{5}{*}{\begin{tabular}{|l|}
4 persons: accounting \& finance \\
manager, account receivable, daily- \\
cash staff, taxes staff, daily-record \\
staff (15 documents 5 days x 5 \\
hours)
\end{tabular}} & \multirow{5}{*}{375} & 93,370 & $35,013,656$ \\
\hline & & & & 30,712 & $11,516,852$ \\
\hline & & & & 29,823 & $11,183,743$ \\
\hline & & & & 30,173 & $11,314,968$ \\
\hline & & & & 28,424 & $10,658,844$ \\
\hline \multirow{5}{*}{9} & \multirow{5}{*}{ Financial Statements } & \multirow{5}{*}{$\begin{array}{l}4 \text { persons: accounting \& finance } \\
\text { manager, account receivable, daily- } \\
\text { cash staff, taxes staff, daily-record } \\
\text { staff (15 documents x } 5 \text { days x } 5 \\
\text { hours) }\end{array}$} & \multirow{5}{*}{125} & 93,370 & $11,671,219$ \\
\hline & & & & 30,712 & $3,838,951$ \\
\hline & & & & 29,823 & $3,727,914$ \\
\hline & & & & 30,173 & $3,771,656$ \\
\hline & & & & 28,424 & $3,552,948$ \\
\hline \multicolumn{5}{|c|}{ Total Resources Costs } & $168,279,034$ \\
\hline
\end{tabular}

e. Production process activities

\begin{tabular}{|c|c|c|c|c|c|}
\hline No. & $\begin{array}{c}\text { Primary Activity } \\
\text { Description }\end{array}$ & Resource Capacity & $\begin{array}{c}\text { Processing } \\
\text { Time } \\
\text { (Hours) }\end{array}$ & $\begin{array}{c}\text { Standard } \\
\text { Hourly Fee } \\
\text { (IDR) }\end{array}$ & $\begin{array}{l}\text { Resources Fee } \\
\text { (IDR) }\end{array}$ \\
\hline \multirow{9}{*}{1} & \multirow{9}{*}{$\begin{array}{l}\text { Finishing Modul E- } \\
\text { learning: } \\
\text { CBT Development }\end{array}$} & \multirow{9}{*}{$\begin{array}{l}12 \text { person: supervisor produksi, } \\
\text { instructional designer, graphic } \\
\text { designer, ilustrator, programmer, } \\
\text { content writer, voice over. ( } 230 \\
\text { days } \times 7 \text { hours) }\end{array}$} & \multirow{9}{*}{1610} & 82,493 & $132,814,195$ \\
\hline & & & & 34,610 & $55,722,258$ \\
\hline & & & & 41,031 & $66,059,517$ \\
\hline & & & & 37,606 & $60,546,413$ \\
\hline & & & & 15,210 & $24,488,330$ \\
\hline & & & & 21,680 & $34,904,181$ \\
\hline & & & & 72,929 & $117,415,942$ \\
\hline & & & & 2,019 & $3,250,336$ \\
\hline & & & & 4,786 & $7,706,006$ \\
\hline \multicolumn{5}{|c|}{ Total Resources Costs } & $502,907,179$ \\
\hline
\end{tabular}

5) Calculate the level of employee resource capacity utilization for an e-learning project.

Calculation of capacity utilization rates by comparing effective working hours with planned working hours involves the working hours of all employees involved in the primary activities of the e-learning project work process. Related calculations will be shown in the following table:

Table 7. Employee Resource Capacity Utilization 


\begin{tabular}{|c|c|c|c|c|c|c|}
\hline No. & Position & $\begin{array}{c}\text { Number of } \\
\text { Employees } \\
\text { (Persons) }\end{array}$ & $\begin{array}{c}\text { Capacity of } \\
\text { Time-Work } \\
\text { Required } \\
\text { (Hour) }\end{array}$ & $\begin{array}{c}\text { Capacity of } \\
\text { Effective } \\
\text { Time-Work } \\
\text { (Hour) }\end{array}$ & $\begin{array}{c}\text { Capacity } \\
\text { Used }\end{array}$ & Status \\
\hline \multicolumn{7}{|c|}{ a). Employees with multi functions: } \\
\hline & Business Manager & 1 & 1,100 & 1,486 & $74.02 \%$ & under capacity \\
\hline & Accounting \& Finance Manager & 1 & 525 & 1,486 & $35.33 \%$ & under capacity \\
\hline & Human Resources Deparment & 1 & 550 & 1,486 & $37.01 \%$ & under capacity \\
\hline & Sales Marketing & 1 & 770 & 1,486 & $51.82 \%$ & under capacity \\
\hline & Account Receivable Deparment & 1 & 556 & 1,486 & $37.42 \%$ & under capacity \\
\hline & Daily-Cash Staff & 1 & 500 & 1,486 & $33.65 \%$ & under capacity \\
\hline & Taxes Staff & 1 & 514 & 1,486 & $34.59 \%$ & under capacity \\
\hline & Daily-Record Staff & 1 & 500 & 1,486 & $33.65 \%$ & under capacity \\
\hline & General and Administrative Staff & 2 & 280 & 2,972 & $9.42 \%$ & under capacity \\
\hline \multicolumn{7}{|c|}{ b). Employees in the production process (available): } \\
\hline \begin{tabular}{l|l|l}
1 & Suf \\
\end{tabular} & upervisor Produksi & 1 & 1,902 & 1,486 & $127.99 \%$ & over capacity \\
\hline 2 Ins & sstructional Designer & 1 & 1,645 & 1,486 & $110.70 \%$ & over capacity \\
\hline \begin{tabular}{l|l|}
3 & $G r$ \\
\end{tabular} & raphic Designer & 1 & 1,610 & 1,486 & $108.34 \%$ & over capacity \\
\hline 4 Illus & ustrator & 1 & 1,610 & 1,486 & $108.34 \%$ & over capacity \\
\hline \multicolumn{7}{|c|}{ c). Employees in the production process (additional) } \\
\hline \begin{tabular}{l|l|}
1 & $\operatorname{Ins}$ \\
\end{tabular} & nstructional Designer & 2 & 3,290 & 2,972 & $110.70 \%$ & over capacity \\
\hline $2 \quad G r$ & iraphic Designer & 2 & 3,220 & 2,972 & $108.34 \%$ & over capacity \\
\hline \begin{tabular}{l|l}
3 & $\operatorname{Prc}$ \\
\end{tabular} & rogrammer & 1 & 1,610 & 1,486 & $108.34 \%$ & over capacity \\
\hline \begin{tabular}{l|l}
4 & $C_{0}$ \\
\end{tabular} & Ontent Writer & 1 & 1,610 & 1,486 & $108.34 \%$ & over capacity \\
\hline \begin{tabular}{l|l}
5 & $V_{0}$ \\
\end{tabular} & oice Over & 2 & 3,220 & 2,972 & $108.34 \%$ & over capacity \\
\hline & Total & & & & & \\
\hline
\end{tabular}

The table above shows that there are excess levels of resource capacity utilization for several employees, namely the resources of employees who are directly involved with the production process. This means that there is over capacity in the use of employee resource capacity in the production process. With over capacity status in the resources of employees who are directly involved in the production process, companies must consider increasing the number of employees' resources, especially those directly involved in the project output production process. This can provide benefits in terms of the completion time of the e-learning project production process, which will certainly give the company a positive value from the clients.

\section{Allocation of Employee Costs into Product Costs / Outputs for 2017}

The second stage is in developing an activity-based budgeting model, which is calculating the total amount of product / output costs. This calculation is based on the time-driven $\mathrm{ABC}$ that has been calculated. Product costs are obtained from the total capacity usage of each employee position that is charged for each main activity carried out in connection with the company's work process. In this stage, one by one the costs of resources are allocated to each of the main activities of the e-learning project. The calculation of each allocation is as follows:

Table 8. Allocation of Employee Costs to Products/Output

\begin{tabular}{|c|c|c|c|c|c|c|c|}
\hline \multirow[b]{2}{*}{ Position } & \multirow[b]{2}{*}{$\begin{array}{l}\text { Sumber of } \\
\text { Imployers } \\
\text { (Persons) }\end{array}$} & \multicolumn{5}{|c|}{ Main Actinitios } & \multirow[b]{2}{*}{$\begin{array}{l}\text { Total Product } \\
\text { Cost } \\
\text { (IDR) }\end{array}$} \\
\hline & & $\begin{array}{l}\text { Price Offer } \\
\text { (IDR) }\end{array}$ & $\begin{array}{c}\text { Elearning } \\
\text { Module Order } \\
\text { (IDR) }\end{array}$ & $\begin{array}{l}\text { Resourres } \\
\text { Adjustment } \\
\text { (DRR) }\end{array}$ & $\begin{array}{c}\text { Document } \\
\text { (DR) }\end{array}$ & $\begin{array}{l}\text { Production } \\
\text { Process } \\
\text { (DR) }\end{array}$ & \\
\hline \multicolumn{8}{|l|}{ 2). Employes with mulif functions: } \\
\hline 1 Business Nangerer & 1 & $79,646,24$ & $5,171,852$ & . & $28,962,372$ & . & $113,780,78$ \\
\hline \begin{tabular}{|l|l|}
2 & Acounting \& Finance Manoger \\
\end{tabular} & 1 & $2,334,24$ &. & 7 & $46,684,874$ & . & $49,019,118$ \\
\hline \begin{tabular}{|l|l|}
3 & Himan Rerources Depantent \\
\end{tabular} & 1 & &. & $28,64,582$ & $\cdot$ & - & $28,164,582$ \\
\hline \begin{tabular}{|l|l|}
4 & Sales Manteing \\
\end{tabular} & 1 & $24,268,613$ &. & $\cdot$ & $2,466,861$ & 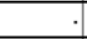 & $26,695,474$ \\
\hline 5 Account Receviable Depament & 1 & . &. & . & $17,055,653$ & & $17,005,653$ \\
\hline \begin{tabular}{|l|l|}
6 Daily-Casin Sanf \\
\end{tabular} & 1 &. &. & . & $14,911,657$ & & 14911,657 \\
\hline \begin{tabular}{|l|l|}
1 & Iares Staff \\
\end{tabular} & 1 &. &. &. & $15,50,49$ & & $15,509,49$ \\
\hline 8 Daily-ReordS Staff & 1 & . &. & . & $14,211,992$ & & $14,211,99$ \\
\hline \begin{tabular}{|l|l}
9 & General and Administrative Safff \\
\end{tabular} & 2 & $2,991,534$ &. &. & $4,187,301$ & & $6,978,855$ \\
\hline \multicolumn{8}{|c|}{ b). Emplogeses in the production process (arailable): } \\
\hline \begin{tabular}{|l|l}
1 & Sippensisor Produlasi \\
\end{tabular} & 1 & & . & 989,919 & $23,088,121$ & $132,814,195$ & $156,902,36$ \\
\hline \begin{tabular}{|l|l|}
2 & hsstnctional Dexigger \\
\end{tabular} & 1 & & 346,101 & 4 & $1,211,353$ & $55,72,258$ & $57,279,712$ \\
\hline 3 Grạtic Desigher & 1 & &. &. & 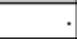 & 66,59,5,517 & $660,099,517$ \\
\hline \begin{tabular}{|l|l|}
4 & lissuabr \\
\end{tabular} & 1 & &. & . & - & $60,546,413$ & $60,546,413$ \\
\hline \multicolumn{8}{|c|}{ c). Employeses in the production process (additional) } \\
\hline \begin{tabular}{|l|l|}
1 & Instinctional Dexigger \\
\end{tabular} & 2 & . &. & $\cdot$ & & $24,488,30$ & $24,488,330$ \\
\hline \begin{tabular}{|l|l}
2 & Gruphic Desigerer \\
\end{tabular} & 2 & $\cdot$ &. & . & . & $34,90,181$ & $34,904,181$ \\
\hline \begin{tabular}{|l|l|}
3 & Progranmer \\
\end{tabular} & 1 & . & $\cdot$ & $\cdot$ & 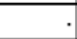 & $117,415,942$ & $117,415,42$ \\
\hline \begin{tabular}{|l|l|}
4 & Content Writer \\
\end{tabular} & 1 & &. & 7 & & $3,250,336$ & $3,250,336$ \\
\hline 5 Vonce Cher & 2 & &. & $\cdot$ & . & $7,706,066$ & $1,706,060$ \\
\hline \multicolumn{2}{|l|}{ Total } & $109,41,914$ & $5,517,9,53$ & $29,15,001$ & $168,179,034$ & $502,907,179$ & $814,899,582$ \\
\hline
\end{tabular}

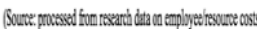

The table above shows the total cost of project elearning are IDR.814,899,582. The largest product costs are in the cost of employees who focus on the activities of the production process in the amount of IDR.528,552,674 or around $64.86 \%$ of the total product cost. So, it can be concluded that of the five main activities in the work process under study, the production process activity is the main activity that requires the proportion of working hours and the highest cost of employee resources owned by the company.

The results of this calculation are clearly different from the standard portion set by the company in the realization of the use of employee costs. Whereas in the realization of the budget, the company still uses an incremental budgeting budgeting system, which displays a smaller number of employee costs. Calculation in activity-based budgeting has been supported by processed data from interviews with employees involved in the e-learning project work process and the results of documentation from company archives. This certainly needs to be considered by the company in terms of determining 
the percentage of fixed costs charged to the project costs, so that the actual profit value can be obtained.

\section{Conclusion}

1. Costs that play a dominant role in the cost of resources supporting the work operations of elearning projects are employee costs. In the implementation of the activity-based budgeting model, the employee costs incurred for all major activities in the completion of the e-learning project amounted to IDR.814,899,582. Whereas prior to the implementation of the activity-based budgeting model, the company only recognized the total employee costs of IDR.391,805,547, for the completion of the e-learning project. So that there is a difference of IDR.423,094,035. This difference is caused by differences in budgeting models in calculating the costs of employees. Calculation in the activity-based budgeting model uses a calculation of costs based on each activity related to the completion of the e-learning project. So that the actual cost of the project activities is IDR.814,899,582. Whereas previously the company implemented an incremental budgeting model, where the calculation of employee costs was obtained through the percentage of revenue comparison of e-learning projects to total revenue during 2017. So that the recognized employee costs were only IDR.391,805,547, far from the amount of employee costs calculated with the activity-based budgeting model. This shows that the activity-based budgeting model provides more accurate information on the number of employee costs.

2. In terms of working time allocation for each activity from employee resources in order to complete the work process to produce elearning project output, there are several employees who experience under capacity conditions which result in the use of hourly resource costs being less effective. Some employees who experience under capacity conditions are multi-functional employees, with working hours of $25.98 \%$ to $90.58 \%$ under effective working hours per year set by the company. Of all employees who experienced under capacity conditions, employees with general and administrative staff positions were employees with the lowest activity hours of only $9.42 \%$ of the total $100 \%$, with 2 employees. In addition, there are also some employees who are over capacity with working hours of activities exceeding effective working hours per year, so that employees receive income not in accordance with the working hours of their activities. Some employees who experience over capacity conditions are employees who are directly related to the e-learning production process, with working hours of $8.34 \%$ to $27.99 \%$ above the effective working hours per year set by the company. Employees who experience the highest over capacity condition are employees with production supervisor positions, with working hours of $27.99 \%$ above effective working hours per year. The condition of over capacity has an impact in terms of the completion time of the e-learning output production process activities, which were originally planned to be completed in 96 working days, but in the realization of the completion of the production process takes 230 days or around $139.58 \%$ above the planned completion time.

3. The implementation of activity-based budgeting provides more accurate and accurate information about the number of employee costs that are calculated based on employee costs for each major activity related to e-learning projects so as to produce more appropriate project profit information. Prior to the implementation of activity-based budgeting, the company divided the average portion for all cost components including employee costs. This has resulted in inappropriate information on employee costs for related projects, resulting in information on the achievement of project profits that are also inappropriate. The profit of the project before the implementation of activity-based budgeting was IDR.395,641,525. After calculating employee costs using the activity-based budgeting model, it turns out that the company experienced a loss for e-learning projects, amounting to IDR.4,899,582. So that it can be said that the company is less precise in determining the offer price or selling price for elearning projects. This is certainly because from the beginning the company was not right in calculating employee costs which is a management reference in determining the offer price or selling price.

4. The implementation of activity-based budgeting provides accurate information about the number of employee resources needed in the work process. Initially the company only provided a workforce of 22 people to complete e-learning projects. However, after calculation with the activity-based budgeting model, it turned out 
that the workforce needs for project completion were 30 people, with the condition of adding 9 workers to the production process and reducing the number of employees in the general and administrative sections. This can be taken into consideration for company management, especially in terms of adding employees to positions that are directly involved in the production process activities because of over capacity.

\section{References}

[1] G. Mutanov, Mathematical Methods and Models in Economic Planning, Management and Budgeting, 2nd ed. New York: Springer Heidelberg, 2015.

[2] M. Mowen, D. Hansen, and D. Heitger, Cornerstones of Managerial Accounting, 6th ed. Canada: Cengage Learning, 2016.

[3] P. Weetman, Financial and Management Accounting, 6th ed. United Kingdom: Pearson Education Limited, 2013.

[4] D. Janikova, "Draving Up a Budget Using the Activity Based Budgeting Methodology Through the Simulation of Processes," Kval. Inovácia Prosper. / Qual. Innov. Prosper., vol. 15, no. 2, pp. 18-30, 2011.

[5] C. Drury, Management and Cost Accounting, 10th ed. United Kingdom: Cengage Learning, 2018.

[6] Nengzih, "Corporate governance, Environmental Management Accounting and Financial Performance of Indonesia's State Owned Companies," Int. J. Business, Econ. Law, vol. 9, pp. 1-9, 2016.

[7] H. Setiyawati, Mutiah, and Nengzih, "The Effect of the Implementation of Good Corporate Governance Principles and the Effectiveness of Internal Control System Disclosure of Environmental Accounting and its Implications on the Company Performance (Studies in State-Owned and Private Hospitals ," Res. J. Financ. Account., vol. 5, no. 24, pp. 172-177, 2014.

[8] Nengzih, "Corporate Governance, Internal Control and Voluntary Disclosures of Environmental Accounting to Company Performance: Evidence from Hospital Industries in Indonesia," Res. J. Financ. Account., vol. 22, no. 5, pp. 134-145, 2014.

[9] C. Warren, J. Reeve, and J. Duchac, Financial and Managerial Accounting, 13th ed. United Kingdom: Cengage Learning,
2016.

[10] R. Pockeviciute, "The Theoretical Model of Activity-Based Budgeting in Agricultural Enterprises," Alytus City Munic. Adm. From EPSA-European Public-Sector Award, pp. 227-232.

[11] R. Kaplan and S. Anderson, What-If Analysis and Activity-Based Budgeting: Forecasting Resource Demands. Harvard: Harvard Business School Publishing Corporation, 2008.

[12] E. Moustafa, "An Application of ActivityBased-Budgeting in Shared Service Departments and Its Perceived Benefits and Barriers under Low-IT Environment Conditions," J. Econ. Adm. Sci., vol. 21, no. 1, pp. 42-72, 2005.

[13] S. Capusneanu and S. Ileana, "Implementation of Activity-Based Budgeting Method in The Economic Entities from Mining Industry of Romania," Int. J. Acad. Res. Accounting, Financ. Manag. Sci., vol. 3, no. 1, pp. 26-34, 2013.

[14] Z. Pietrzak, "Traditional Versus ActivityBased Budgeting in Non-Manufacturing Companies," Soc. Sci., vol. 82, no. 4, pp. 2637, 2013.

[15] R. Pockeviciute, "Case Study: Activity Based Budgeting at Agricultural Holdings in Lithuania," Econ. Rural Dev., vol. 4, no. 2, pp. 26-34, 2008.

[16] S. . Oneshko and M. . Boiko, "Activity-Based Budgeting as A Management Tool of Economic Security of Stevedoring Company," Sci. J., vol. 25, no. 3, pp. 134143, 2016.

[17] S. K. Maheshwari, "An Application of Activity Based Costing in Local Government Budgeting," Delhi Bus. Rev., vol. 1, no. 1, 2000.

[18] W. Carter, J. F. Hwang, and S. Te Chou, Cost Accounting: An Asia Edition. Taiwan: Cengage Learning, 2015.

[19] A. Bhimani, C. Horngren, S. Datar, and M. Rajan, Management and Cost Accounting, 6th ed. Edinburgh Gate United Kingdom: Pearson Education Limited, 2016.

[20] T. Huynh, G. Guangming, and H. Huyhanh, "Integration of Activity-Based Budgeting and Activity-Based Management," Int. J. Econ. Financ. Manag. Sci., vol. 1, no. 4, pp. 181187, 2013.

[21] U. Sekaran and R. Bougie, Research Methods for Business, 7th ed. West Sussex: John 
Wiley \& Sons, 2016.

[22] Sudaryono, Metodologi Penelitian. Jakarta: Rajawali Pers, 2017.

\section{Author Profile}

Wayan Santiasih, was born in Balinuraga on September $9^{\text {th }}, 1990$. She obtained the Bachelor of Economy from Sekolah Tinggi Ilmu Ekonomi Indonesia, Jakarta in 2012 with the cum laude predicate. From 2016 to present, she is a Master Student in Accounting Department, Universitas Mercu Buana, Jakarta, Indonesia. Her research concerned with budgeting model field. Currently, she works at one of IT Enterprise in Jakarta,
Indonesia, as a Accounting and Finance Manager. It became her primary occupation since 2012 .

Associate Prof. Dr. Nengzih, was born in Makassar City on February $1^{\text {th }}$, 1972. Until Now She is an accounting lecturer from Universitas Mercu Buana, Jakarta, Indonesia. She held Doctoral Degree in accounting from Universitas Padjajaran, Bandung, West Java in 2015. And hold master degree from financial management at Universitas Hasanuddin, Makasar. 